\title{
A percepção de variação em semitons descendentes em palavras isoladas no português brasileiro $^{2}$
}

Amanda Lassak

\section{Objetivos}

Este trabalho pretende examinar a sensibilidade de falantes brasileiros na percepção de variação em semitons descendentes em palavras isoladas no Português Brasileiro (PB), tendo por base os estudos desenvolvidos por T'Hart (1980), para o holandês. Além disso, pretende complementar o estudo realizado por Consoni e Ferreira Netto (2008), em relação à percepção de variação em semitons ascendentes.

\section{Material e Métodos}

A fim de avaliar a correlação entre a variação de semitons descendentes e o julgamento dos ouvintes, foram realizados testes de percepção na pesquisa de campo.

Os testes de percepção envolviam 30 sujeitos, com idades entre 20 e 50 anos, de ambos os sexos. Foram apresentados pares de palavras trissílabas, gravados com voz feminina, sendo que os pares continham as mesmas palavras. Os ouvintes deveriam julgar, na transcrição, se havia ou não variação de pronúncia entre os pares considerados.

\footnotetext{
2 SIMPÓSIO INTERNACIONAL DE INICIAÇÃO CIENTÍFICA/USP - SIICUSP, 17. São Paulo, 2009.
} 
A manipulação das palavras foi feita com a função "To Manipulation" do Praat, versão 5.1.03, considerando uma medida de tempo de 0.01s e uma variação de pitch entre 75 e $600 \mathrm{~Hz}$. As palavras foram manipuladas de 1 a 6 semitons abaixo do tom original, levando em conta duas categorias de variação: uma em que todas as sílabas da palavra eram manipuladas e outra em que apenas as silabas tônicas eram manipuladas. A gravação exibida no teste de percepção foi desenvolvida no programa Adobe Audition 3 (free trial).

\section{Resultados e discussão}

Os resultados da pesquisa demonstraram que os sujeitos perceberam variações de 5 e 6 semitons descendentes. Variações de 1, 2 e 3 semitons não foram percebidas, e variações de 4 semitons foram percebidas de forma aleatória $(P=0,62)$.

Tais resultados corroboram as conclusões de T'Hart para o holandês, em que somente diferenças de mais de 3 semitons são perceptíveis aos falantes, desempenhando um papel nas situações comunicativas.

\section{Conclusões}

A análise de correlação demonstrou que existe uma forte correlação entre a variação em semitons descendentes e o julgamento dos ouvintes. A correlação encontrada foi de $R^{2}>$ 0,97 na maioria dos casos. 